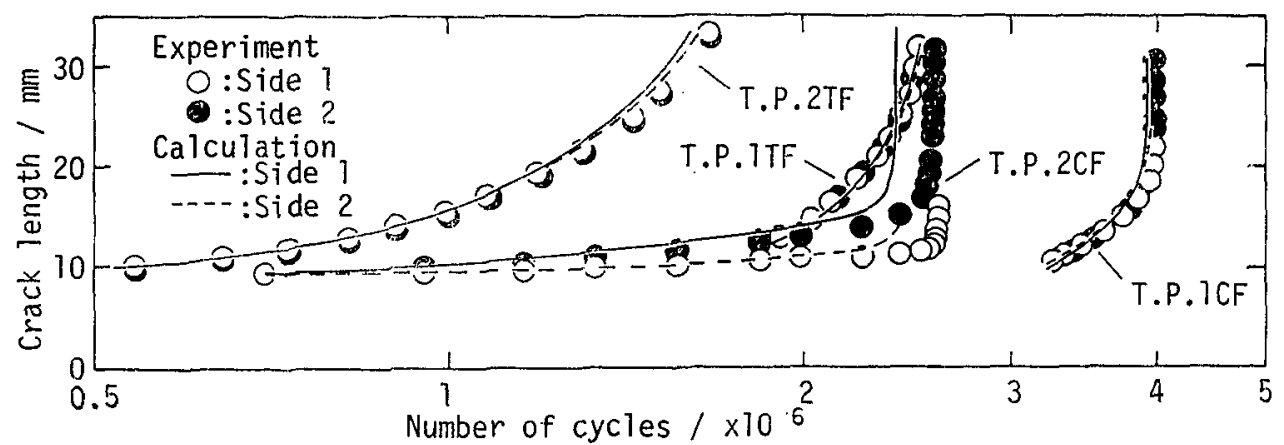

Fig. 7 Prediction of fatigue crack propagation behavior in weld residual stress field

伝播特性より求め, $c=1.53 \times 10^{-11}\left[\frac{m}{\operatorname{cycle}(\mathrm{MPa} \sqrt{m})^{m}}\right]$, $m=2.73$ とした. 従って, き裂成長曲線は次式で与劣ら れる。

$$
N=\int_{a_{1}}^{a_{2}} \frac{d a}{c\left(\Delta \bar{K}_{\mathrm{act}}\right)^{m}}
$$

Fig. 7 は(6)式を数值積分した結果であるが，各溶接残 留応力場でのさ裂伝播挙動は $\Delta K_{\text {act }}$ を用いるととにより 完全開口時の $c$ と $m$ さえわかればすべて非労に良好な 精度で推定し得ることが明らかとなった。

以上より，牫留応力によるき裂の部分開口を考虑した $\Delta K_{\text {act }}$ の考え方を用いるととにより签接残留灾力下にお ける包括的なき裂伀播挙雮の推定が可能となった。ま た， $\Delta K_{\mathrm{act}}$ 概念はいいかえれば $\Delta K_{\text {eff }}$ 概念の搪张形であ

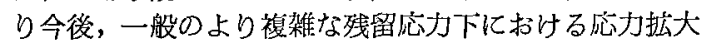
係数への適用の可能性力窺われる。

\section{4. 結 論}

溶接残留応力下に括ける疲学き裂侄播挙動を定量的に 取り扱うためにさ裂部分開口モデルを提案し，その $K$ の算定法について重ね合せの方法の適用を試みた，得ら れた結果を次に示す。

1）き裂が初期残留底力分布引張任縮遷移域に存在す
る場合，き裂は部分開口すると見なせる。

2）部分開口き裂においてその䦎口部がなめらかに閉 口していると仮定すると重祸せの方法により開口部の $K$ が求められる.

3）部分開口き裂の応力拡大係数振幅， $\Delta K_{\text {act }}$ を用い るとよによって溶接残留応力下に拈る応力拡大係数振 幅はすべて表示できる。

4) $\Delta K_{\text {act }}$ を用いるととにより溶接板中での度学き裂 伝播举動の推定が可能となり，その垁用性が明らかに なった。

\section{参 考 文 献}

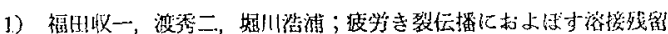

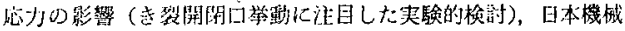
学会, Vol.47, No.416 (暗56-4), 384-390

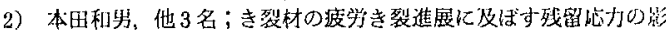
留，材料，Vol.31，No.348，炤57.9，908-914

3) G. Glinka ; Effect of Residual Stress on Fatigue Crack Growth in Steel Weldments under Constant and Variable Amplitude loads, ASTM STP 677, 1979, 198-214

4) P.C. Paris and F. Erdgan; A Critical Analysis of Crack Propagation Laws, Trans. of ASME, Journal of Basic Engineering, Series D, 85, No.3, 1963

\title{
圧縮残留応力場から伝播する疲労き裂の開閉口挙動に 関する解析的検討*
}

\author{
向井罳 彦**，西村新**
}

\author{
Opening and Closure Analysis for Fatigue Crack Propagated from \\ Gompressive Residual Stress Field*
}

by Yoshihiko Mukai** and Arata Nishimura**

Initial residual stress due to welding was produced by thermo-elasto-plastic analysis based on F.E.M. calculation, thereafter cyclic-elasto-plastic analysis for fatigue crack propagation was carried out. A crack was propagated by $0.2 \mathrm{~mm}$ per one load cycle from compressive residual stress field to tensile stress field (stress ratio was 0.0 ). Crack opening and closing behavior was investigated in relation to re-distribution of residual stress and change of plastic region.

Main results obtained are summarized as follows:

1. When the crack tip was in the stationary compressive residual stress field, as crack planes were kept 
in contact, the re-distribution of residual stress did not occur so much at unloading state. The crack opening was occurred at the crack root then moved to the crack tip, and this was also recognized in base metal analysis.

2. As the crack approached the initial tensile residual stress field, the residual stress re-distributed and the crack-opened-region remained near the crack tip even at unloading. The crack opening points were moved both to crack tip side and crack root side, and the crack tip opening occurred earlier than the full crack opening.

3. It was clarified that crack opening stress level would be able to be determined by strain gages glued just behind the crack tip, and using superposition model, the stress level could be estimated from the compressive residual stress distribution on the crack plane.

Key Words: Residual stress distribution, Fatigue crack, Crack opening stress, Thermal-clasto-plastic analysis, Cyclic-clasto-plastic analysis, F.E.M.

\section{1. 緒言}

溶接残留応力は将学き裂の発生・伝播仁大き関与す るため, 今日溶接構造物の性能評俩にあたって, 疲労き 裂伝播に及ほす溶接残留灾力の影響を考慮するととは避 けられない課題となっている。

疲労き裂伝播はき裂先端およびき裂面上に存在する残 留塑性歪などに起风したさ裂開閜口挙動によって影響さ れることが知られており"，有效応力掋大係数の笵囲に よる伝播速度の整理が数多く行なわれている。裂開口

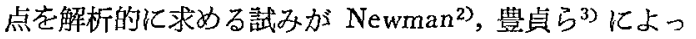
てなされているが，溶接残留応力場といった内部応力場 が存在する場での解析手法については必ずしも明らかで ない.

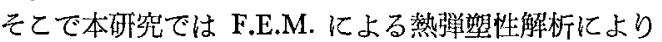

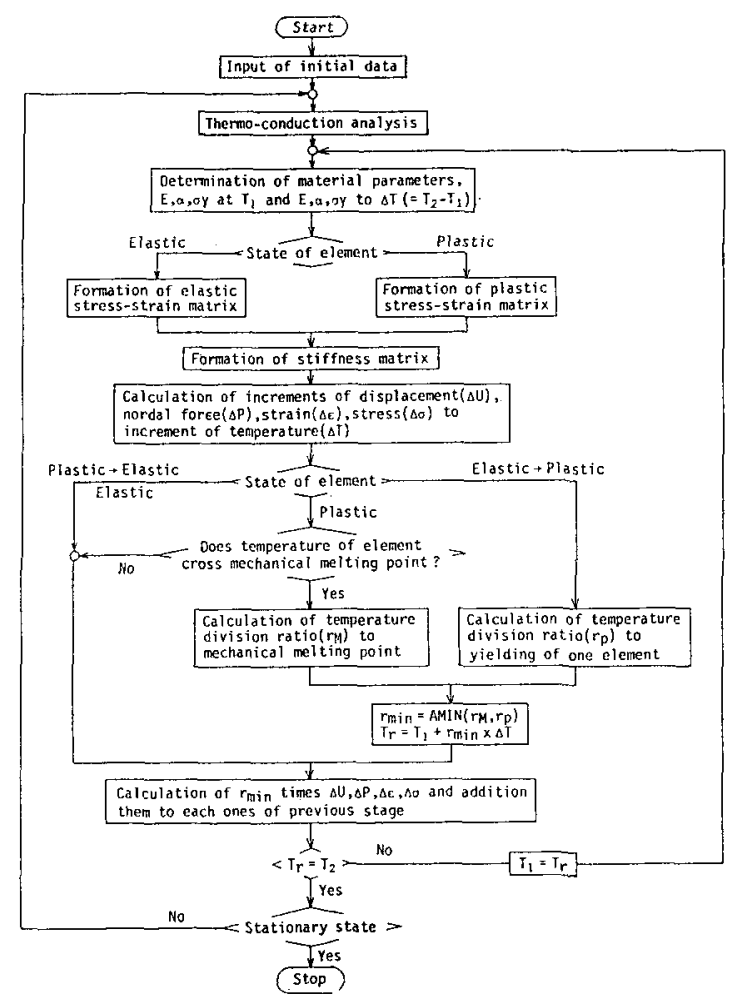

Fig. 1 Flow chart of thermo-elasto-plastic analysis
溶接残留㾔力場を再現し，さらに絽返し弾塑性解析を行 ない溶接残留応力場でのき裂開口挙贸について検討し た.

初期引張残留応力場（以下 ITRSF 上記す）加らさ裂 が伝播する時には，残留応力場が再分布しき裂先端に常 に引張残留応力が集中するため，無負荷状態であって

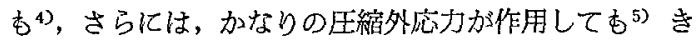
裂は啊口しにくくなる。しかしながら，初期压縮残留応 力場（以下 ICRSF 之記す）加ら伝播する場合には残留 応力場がはとん亡゙再分布せず，そのためき裂は開口しに くくなる゙．また ICRSF から ITRSF へとき裂が伝播 するとき裂面上に残存開口部が生じるといった複雑な開 閉口挙陲か観祭される4). こういった压縮残留応力場の

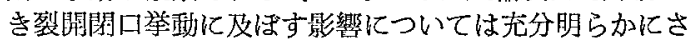
れておらず，てのため ICRSF から伝播する疲労 き裂を対象として 解析的検討を行なうこととし た.

\section{2. 解 析 方 法}

\section{1 熱弾弾性解析}

溶接による残留応力を評価するためまず熱弾塑

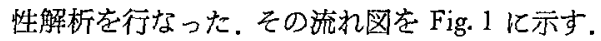
熱伝覚解析プログラムは水本, 原のプログラム 6,7$)$

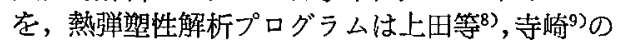
研究を参考にして作成した。

まず始的に熱层導解析によって各節点の温度增 分を求め, 要素を構成する三節点の温度の平均値 を各要素の温度とし各要素の温度增分を 決定す る. 次に前段階での村料定数を用いて熱弾望性解 析を行ない，その温度增分に 刘する要素の歪增 分, 応力増分を求め, 前段階での值们加算し現段 階での応力・歪状態を決定する，乙の手順を定常 温度状態（全要素中の最高温度々最低温度の差が $20^{\circ} \mathrm{C}$ 以下）になるまで絽返し，初期残留応力場を 求めた。なお，熱源となる節点に対しては強制加 熱・冷却老行ない，一つの温度增分区間で全要素 の温度增分の内で最大となる温度増分が，加熱過 程では $50^{\circ} \mathrm{C}$ 以, 冷却過程では $25^{\circ} \mathrm{C}$ 以上となるよ うにした.

一つの温度增分区間内で弾性↔塑性に遷移する 要素の場合には Fig. 2 亿示すように $T_{1}, T_{p}$ 間で 弾性, $T_{p}, T_{2}$ 間で塑性として 取り扱う必要があ る.そこで $\Delta T_{M}\left(=T_{2}-T_{1}\right)$ の間で盜度 $(T)$ と 相当応力 $\left(\sigma_{\mathrm{eq}}\right)$, 降伏応力 $\left(\sigma_{Y}\right)$ の 閐仪線形関 


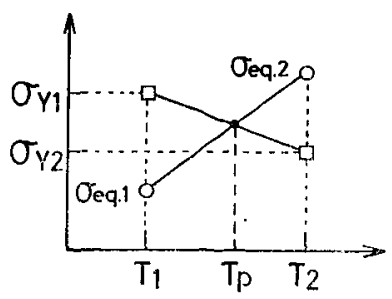

Fig. 2 Definition of temperature division for an element to be yielded

係を仮主し，次式仗よって $T_{p}$ 通邀温度分割比 $\left(r_{p}\right)$ を 定義した。

$$
r_{p}=\frac{\sigma_{\mathrm{eq} .1}-\sigma_{Y_{1}}}{\left(\sigma_{\mathrm{eq} \cdot 1}-\sigma_{Y_{1}}\right)-\left(\sigma_{\mathrm{eq} \cdot 1}-\sigma_{Y_{2}}\right)}
$$

また力少的溶融点 $\left(T_{M}\right)$ を通過する要素に対しては, $\Delta T_{M}$ の間を線形に分割する $T_{M}$ 通過温度分割比 $\left(r_{M}\right)$ を次式によって求めた。

$$
r_{\text {M }}=\left(T_{\boldsymbol{M C}}-T_{1}\right) /\left(T_{2}-T_{1}\right)
$$

式(1)，(2)加ら得られる $r$ の最小のもの $\left(r_{\min }\right)$ を求め, $r_{\min } \cdot \Delta T_{M}$ だけ温度変化させ熱弾望性解析を行ない，さ らに残りの温度增分 $\left(\left(1-r_{\min }\right) \cdot \Delta T_{M}\right)$ 飞対して順次 $r_{\min }$ を求め，各温度増分の和が $\Delta T_{M L}$ と等しくなった時点で 一つの温度增分区間内での熱弹塑性解析を終了すること とした.

\section{2 繰返し弾塑性解析}

疲学き裂伝播に伴うき裂開閉口挙動を検討するため繰 返し弾塑性解析を行なった．解析プログラムの基本棈成 は既報 ${ }^{102}$ と同㥞であるが，本研究ではさらに次の 2 点に ついて改良を加えている。

1）繰返し負荷に伴うバウシンガー效果を表現するた め，浜田等の研究11飞従い移動硬化則之等方硬化則を混 合して用いることとした。この混合割合を TRAS と記 す.TRAS が0.00時は等方硬化則，1.00時は移動硬化 則となる。

2）各繰返し負荷の負荷開始時に一節点ずつ節点の拘 東をはずし，繰返しに伴ってき裂長さを順次增加させ る、ただし拘束をなくした節点の反力が零となるまでは 変位增分は生じない杂の上した。

熱弾塑性解析，繰返し弾塑性解析とむに平面态力状態 とし, 全体岡性マトリックスは共役傾斜法12)を用いて解 いた．また溶接残留応力場での繰返し弘望性解析では熱 弾塑性解析結果をそのまま初期状態として用いた。

\section{3 解析対象および解析条件}

解析対象とした形状および要素分割を Fig. 3 に示す。 このモデル（節点総数211，要素総数 354）は既報 ${ }^{13}$ 亿示 した ICRSF からき裂が伝播する HT 80 帯板試験片を 想定した 1/4モデルである. 溶按ビードに相当する熱源 幅を $5 \mathrm{~mm}$ ，中央から熱源中心までを $30 \mathrm{~mm}$ とした。 図中のの印は前述した強制加熱・冷却節点である。

㷦弾塑性解析ではモデル周辺部を断熱し，力学的拘束 を行なっていない，また表面からの熱放散，潜熱を無視 し，熱拡散率は温度に無関係に $0.001 \mathrm{~m}^{2} / \mathrm{sec}$ 亡した. 降伏応力 $\left(\sigma_{Y}\right)$, 加工硬化係数 $\left(H^{\prime}\right)$, ヤング率 $(E)$, 線 起張係数 $\left(\alpha_{1}, \alpha_{2}\right)$ の温度依存性を以下に示す.

$$
\left.\sigma_{Y}(T)=\left(1-T / T_{\mu}\right) \times \sigma_{Y_{0}}+H_{0}^{\prime} \times \varepsilon_{\mathrm{eq}}^{p}\right)
$$$$
H^{\prime}(T)=\left(1-T / T_{M}\right) \times H_{0}^{\prime}
$$$$
E(T)=1.566 \times 10^{-4} \times T^{3}-4.116 \times 10^{-1} \times T^{2}-4.754 \times T
$$

$$
+1.998 \times 10^{5}
$$
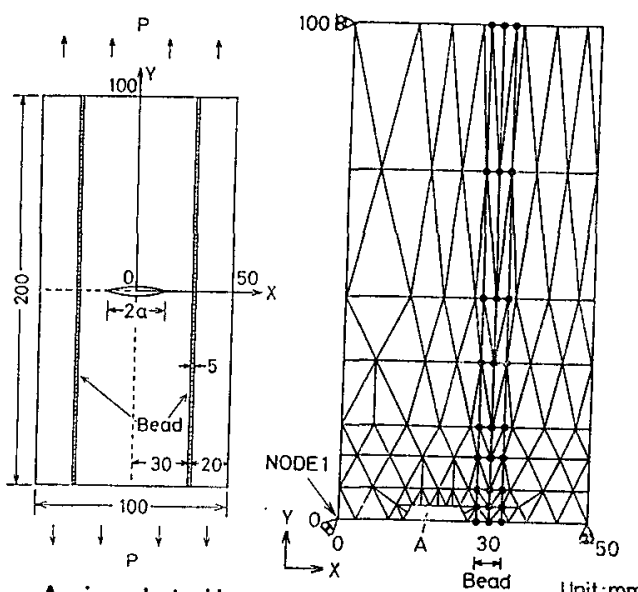

$A$ in detail

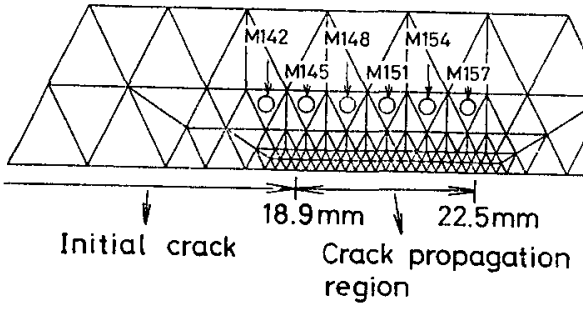

Fig. 3 Mesh division of F.E.M. calculation model

$\alpha_{1}(T)=\left(0.4 \times T / T_{M}+1.05\right) \times 10^{-5}$

$\alpha_{2}(T)=\left(0.25 \times T / T_{M}+1.20\right) \times 10^{-5}$

$T_{\text {AI }}=830^{\circ} \mathrm{C}, \quad \sigma_{Y_{0}}=735.5 \mathrm{MPa}, H_{0}^{\prime}=2206.6 \mathrm{MPa}$, $\nu=0.33$

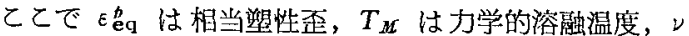

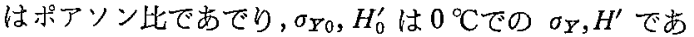
る.これらの値は上田等8), F.C.Lea et $\mathrm{al}^{14)}$ の研究を参 考にして決定した。

HT 80 は加熱・冷却過程で変態膨張を生じるが，乙 れらの変態を考慮するため前記した 2 種類の線膨張係数 $\left(\alpha_{1}, \alpha_{2}\right)$ を用いた。予備的に行なった匀一加晸・均一冷

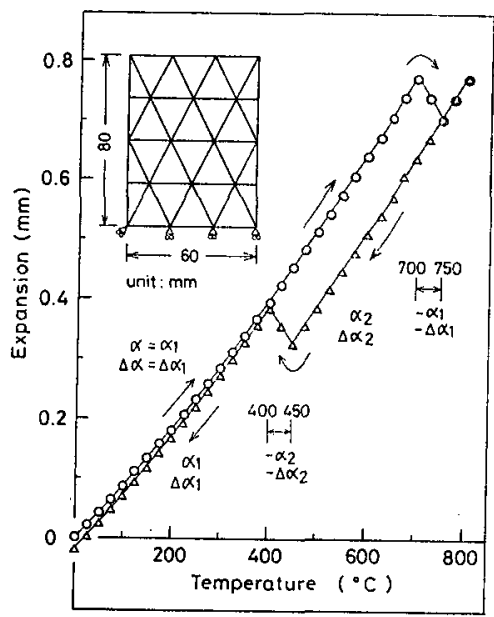

Fig. 4 Dilatometric curve 
Table 1 Material constants and boundary conditions

\begin{tabular}{|c|c|c|c|c|c|}
\hline $\begin{array}{l}\text { Mode } 1 \\
\text { code }\end{array}$ & $\begin{array}{l}\sigma \max . \\
(\text { MPa })\end{array}$ & $\begin{array}{l}\text { (Min. } \\
\text { (MPa) }\end{array}$ & $\begin{array}{c}\sigma_{\mathrm{Y}} \\
(\mathrm{MPa})\end{array}$ & TRAS $\left.{ }^{\star}\right)$ & $\begin{array}{c}\mathrm{H}^{3} \\
(\mathrm{MPa})\end{array}$ \\
\hline BM-A & 83.4 & 0.0 & 764.9 & 0.5 & 2206.6 \\
\hline$B M-B$ & 83.4 & 0.0 & 568.8 & 0.5 & 2206.6 \\
\hline $\mathrm{BH}-\mathrm{C}$ & 83.4 & 0.0 & 764.9 & 0.0 & 2206.6 \\
\hline$B M-D$ & 83.4 & 0.0 & 764.9 & 1.0 & 2206.6 \\
\hline$B M-E$ & 83.4 & 0.0 & 764.9 & 0.5 & 4413.2 \\
\hline$B M-F$ & 137.3 & 0.0 & 764.9 & 0.5 & 2206.6 \\
\hline RSI & 245.2 & 0.0 & 764.9 & 0.5 & 2206.6 \\
\hline RSII & 335.9 & 0.0 & 76.9 & 0.5 & 2206.6 \\
\hline
\end{tabular}

$E=205947 \mathrm{MPa}, \quad \nu=0.33$

*) TRAS: Ratio of kinematic hardening

TRAS $=0.0$ means fuil isotropic hardening model

却の結果を Fig. 4 亿示す。図中に示す温度範囲で $\alpha, \Delta \alpha$ の値を使いわけ変態を表現するとととし た. 図中の実線は熱霆の定義に従って $\alpha$ を温度 で積分した計算值(峏端自由)で，F.E.M.による 結果はそれらの值と良く一致している。なお，冷 却過程での変態避張は最滈到達温度が $600^{\circ} \mathrm{C}$ 以上となる 節点を含む要素に対して生じさせた。

Fig. 3 に示したき裂伝播領域内で残留応力場が圧縮応 力から引張応力に変化するように, 平均温度上昇 $\left(T_{\mathrm{av}}\right.$. が $230^{\circ} \mathrm{C}, 380^{\circ} \mathrm{C}$ の 2 種類の熱弾丝性解析を行なった。 これらの結果をそれぞれ RS I， RS II と記す。また 同一モデルを用いて残留応力のない場合（以下材 （BM）上記す）の絽返し弾塑性解析む行なった。繰返し 弾塑性解析々用いた村料定数, 解析条件を Table 1 亿示 す. 母材では最大応力 $\left(\sigma_{\max }\right), \sigma_{Y}$, TRAS,$H^{\prime}$ を変え たすのについても解析を行なった，RS I ，RS II での 降伏灾力は熱歪による降伏点の上昇を考慮して熱弾塑性 解析時の值より少し大き值を用いた。最大灾力 $\left(\sigma_{\max }\right)$ は初期き裂先端の 3 つの要素が降伏する外応力值とし (BM-F を除く)，最小応力 $\left(\sigma_{\max }\right)$ をすべて塞とした.

Fig. 3 に示したように, き裂伝播領域の最小要素は底辺 之高さが $0.2 \mathrm{~mm}$ の二等辺三角形であり, いずれの解 析であ初期き裂長さを $18.9 \mathrm{~mm}$ とし1サイクル每に $0.2 \mathrm{~mm}$ つつつき裂を伝播させ $22.5 \mathrm{~mm}$ まで能析を行 なった．また図中の○印の要素は後述する外力一歪曲線 を求めた要素である.

\section{3. 解析結果および考察}

\section{1 初期残留応力分布と残留応力の再分布}

き裂断面上の要素の初期残留応力分布お上び節点反力 加ら求めた初期残留応力分布を Fig. 5 亿示す. 節点反力 功の換算は次式によって行なった。

$$
\sigma_{i}=-P_{i} /\left(x_{i+1}-x_{i-1}\right) / 2
$$

ここで $\sigma_{i}$ は節点 $i$ での忍力, $P_{i}$ は節点 $i$ の 節点反 力, $x_{i+1}, x_{i-1}$ は節点 $i$ の左右の節点 $i-1, i+1 の x$ 座 標である. RS I では $T_{\text {av. }}$ が低いため, RS II に比べ ITRSF が狭くなっている。き裂伝播領域を搪大して Fig. 6 亿示す. 要素の応力分布之節点反力から求めた分 布はほほ一致しているととがわかる。本研究ではき裂面 上の応力分布が重要な考察対象となるため以後節点反力 から求めた応力分布を用いることとする. 残留応力場き 裂伝播領域に注目すると, RS I の解析はき裂が常に ICRSF (23. $5 \mathrm{~mm}$ 以上が ITRSF となる) を伝播するも のであり, RS II はき裂が ICRSF から ITRSF (20.7 $\mathrm{mm}$ 以上が ITRSF である) へ進展する解析である.

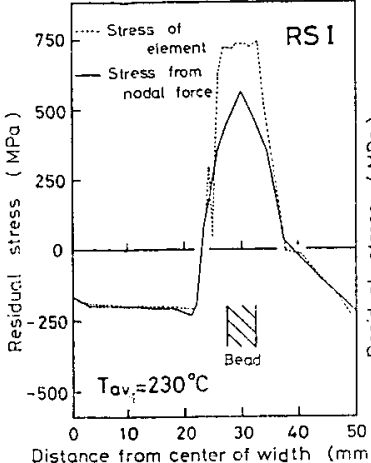

(a)

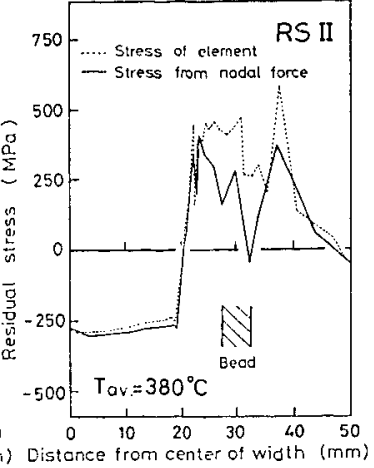

(b)
Fig. 5 Initial residual stress dis tribution by RS I andRS II (a) RS I (b) RS II

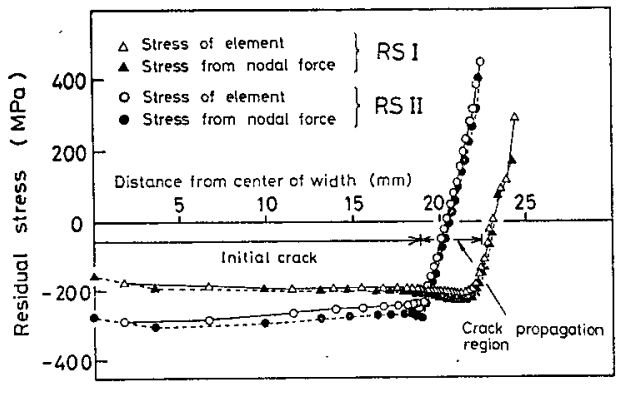

Fig. 6 Particular distribution on crack propagation region

BM-A， RS I， RS II のき裂伝播に伴うき裂伝播領 域での残留応力の再分布を Fig. 7 亿示す. BM-A では き裂先端部に大きな縮残留応力が存在し, 各サイクル でのき裂先端前方の応力分布が類似している．そしてき 裂先端の移動とと屯に応力分布が相似的に平行移動す る. RS I ，RS II の結果でもき裂先端部に著しい圧縮 応力が生じるが，き裂先端前方および後方の分布を見る と，き裂先端が安定した ICRSF にある間 (RSI の Cycle 1，6）はほ上んど場の変化が諗められないのに対し， き裂先端が ITRSF に近づくと（RSI Cycle 18）場が乱 れはじめ，ITRSF にまで進行すると（RS II Cycle 12, 18）場の乱れが大きくなる.

\section{2 塑性域形状の変化}

BM-A，BM-F, RS I , RS II のき裂伝播に伴う塑性 域形状の変化を Fig. 8 亿示す. BM-A ではき裂が伝播 してあ塑性域形状は全く変化しないが，外力を大きくし た BM-F ではしだいに大きくなる。一方 RS I では 塑性域は少しづつ大きくなるが, ITRSF に近づくと $(22.5 \mathrm{~mm})$ 急激に大きくなる。 また RS II では初期に はき裂先端部で小さな塑性域しか形成されないが，(き 裂先端前方の塑性域は熱弹塑性解析により求めた溶 接熱による残留応力によって生じた熱源周辺の要素の塑 性域である.)き裂先端が ITRSF 亿接近すると RS I 々同様急に大きくなり，熱源周辺の塑性域と合体すると と屯にき裂先端近傍の要素恹縮応力によって降伏す る. そしてそれ以後はき裂先端前方に非常に大きな塑性 域が存在するようになる。 


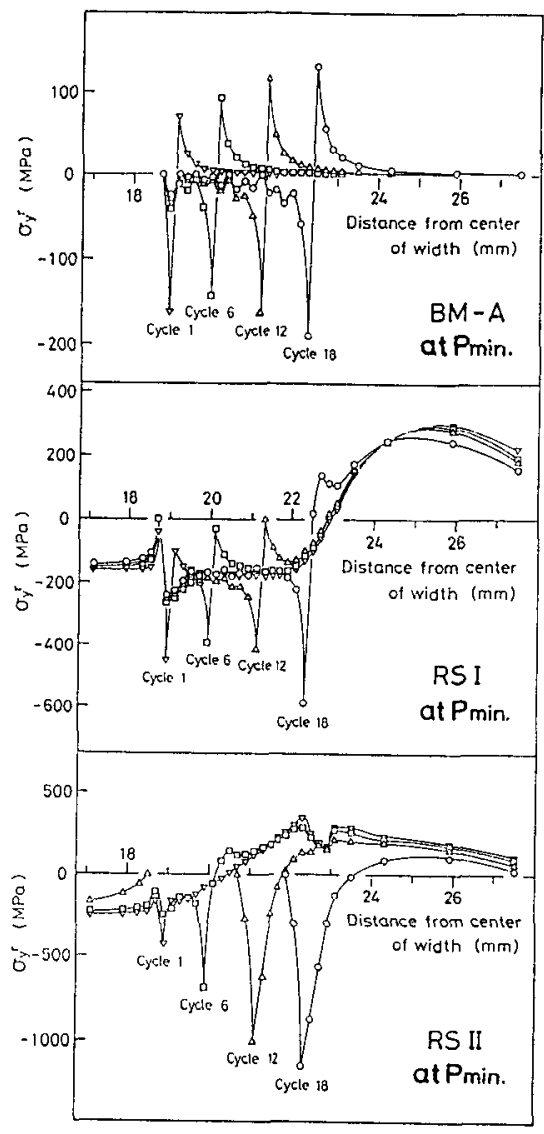

Fig. 7 Change of residual stress distribution around crack tip according to crack propagation at minimum load (Upper; BM-A, Middle; RS I, Lower; RS II)

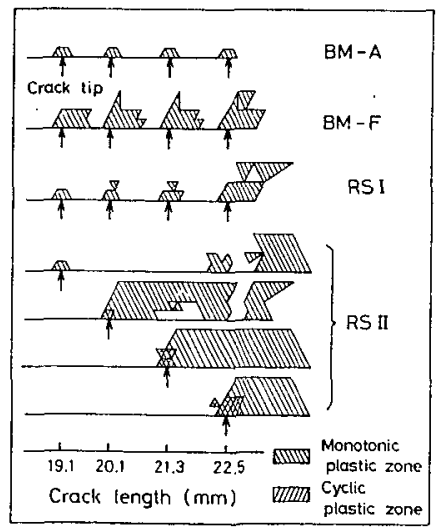

Fig. 8 Variation in plastic region according to crack propagation

以上のことから，き裂先端が ITRSF に近つくと，IT RSF の影響を受けき裂先端前方に大きな塑性域が形成 されるため，き裂面上の残留応力の再分布が生じ始める ことがわかる。

\section{3 き裂閉口学動}

BM-A， RS I， RS II のき裂開閉口の一例を Fig. 9, 10 に示す. BM-A では残留開口変位のない $18.9 \mathrm{~mm}$ から開口し始め，き裂先端に向って開口する，そして除 荷過程ではその逆にき裂先端加ら中央側に向って閉口す る.除荷状熊での残留開口はき裂を $18.9 \mathrm{~mm}$ から伝播 させたために生じたむのである，RS I においてすき裂 は $18.9 \mathrm{~mm}$ から開口し始め，き裂中央部か潤口した後 先端側に向う開口が起こる.除荷過程では先にき裂先端 部が閉口し，その後開口した順とは逆に閉口し，最後に 中央部が閉じる．いずれの掦合もき裂伝播開始点付近の

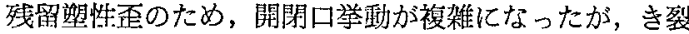
伝播領域に注目すれば，RS I においてもき裂先端側に 向って開口し，除荷過程ではその逆に閉口する，一方き 裂先端が ITRSF に近づくと，き裂先端近傍から開口し 始め (Fig. 10, cycle 7 の $P / P_{\max }=0.56,0.64$ でのき裂 先端側の開口変位)，主としてき裂中央侧に向って開口 する。さらにITRSF にまで裂が進展すると（Fig. 10， Cycle 19), 除荷状態で明らかな残存開口部がき裂先端 付近に残留し，き裂先端が開口した後中央部が開口する ようになる。またこの時，除荷過程では中央部が閉口し た後さ裂先端部が閉じる。この残存開口部は笑験的にす 認められており4)，ICRSF からITRSF へ伝播する疲縤 き裂の一つの特徴と思われる。

現在のき裂先端から 1 つ手前の節点が開口する応力レ ベルを Tip op. (この特の応力を $\sigma_{o p}$ と記す)，その節 点が閉日する応力レベルを Tip cl. (との時の応力を $\sigma_{c l}$ と記す），䏽サイクルでき裂先端から１つ乎前であった 節点が現サイクルで間口する応力レベルを Tip on prestage op. とし,さらにき裂面全体が開日する応力レベル を Full op. と烀ぶことにする.とれらの広力レベルの
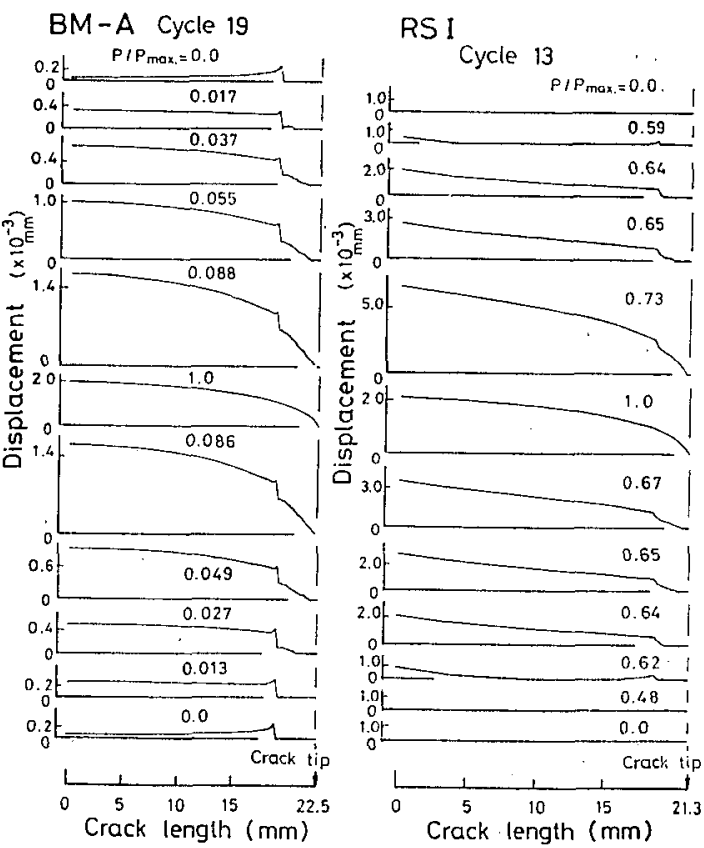

Fig. 9 Change of crack profile on crack opening and closing process (Left side; BM-A Cycle 19, Right side; RS I Cycle 13) 


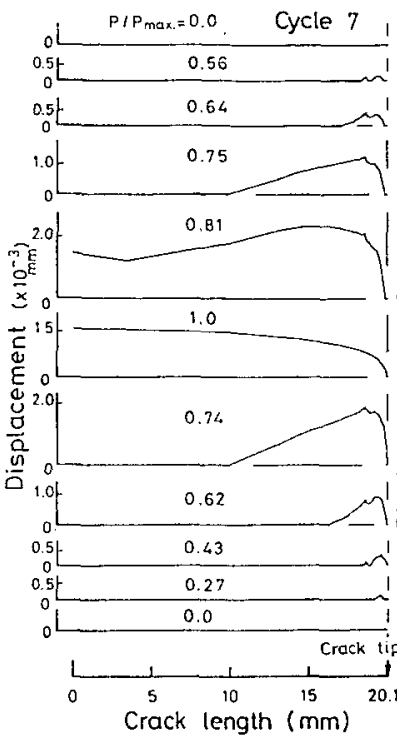

RS II

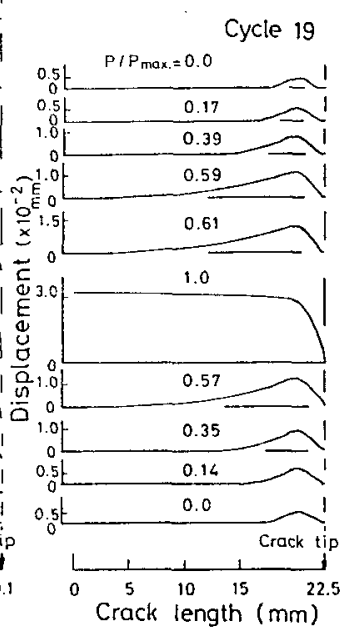

Fig. 10 Change of crack profile on crack opening and closing process of RS II (Left side; Cycle 7, Right side; Cycle 19)

繰返し負荷に伴う変化を Fig. 11 と示す. BM-A, RS I では前サイクルの Tip cl. と現サイクルの Tip on prestage op. が一致し, Tig op. は繰返し負荷に伴って上昇 する傾向にある。これはき裂先端か閉口してから次に開 口するまで弾性的な挙動をするととを示しており，また 残留応力の程度によって開口点がわずか江変化するとと を示している。一方，ITRSF にき裂先端が近づくと (RS II, Cycle 7 以降), 逆降伏のため現サイクルの Tip on pre-stage op. と前サイクルの Tip cl. がー致しなく なる。またき裂中央部が開口した後に先端部が開口し， 中央部が閉口した後先端部が閉口するという挙動を示す ため Tip op. と Tip cl. が大きくずれる.き裂先端が ITRSF に入ると Tip op. と Full op. のずれを生じ, Tip op. は殚調に低下する。

これらの解析結果から(1)き裂面が接触することによっ て压縮残留応力場加長期間住渡って保存されるとと，(2) 内部応力場の平衝を保つために引㖘残留応力場屯初期状 態とほぼ同じ位置に残存するとと，(3)き裂が弓張残留応 力場に進展するとき裂先端部前方に局部的な弓張残留応 力の集中か起こり，除荷状態においてき裂開口させてお くだけの效果を有していることがわかる．従来より圧縮 残留応力場加引伝播する瘦労き裂の伝播速度を応力払大 係数管囲 $(\Delta K)$ に詨して整理すると ICRSF から ITR SF に遷移する付近で伝播速度が急激に大きくなること が知られているが(5,16)，とれは上述したき裂先端部の開 閭口挙動の急激な変化化よるものであるうと推測され る.

\section{4 き裂面近傍要素の外応力-歪曲線}

実駼的にき裂の開閉口挙動を求砋際に，き裂面近傍 に歪ゲージを貼付し荷重一歪曲線を測定するが，ゲージ 長の関係でゲージ中央部はき裂面から $1 \sim 2 \mathrm{~mm}$ 離れた 位置となる。そこでき裂面加ら $1.2 \mathrm{~mm}$ 離れた断面上に 要素重心のある要素の荷重-歪曲線㧍よびき裂中央の 節 点の荷重-変位曲線について検討する。
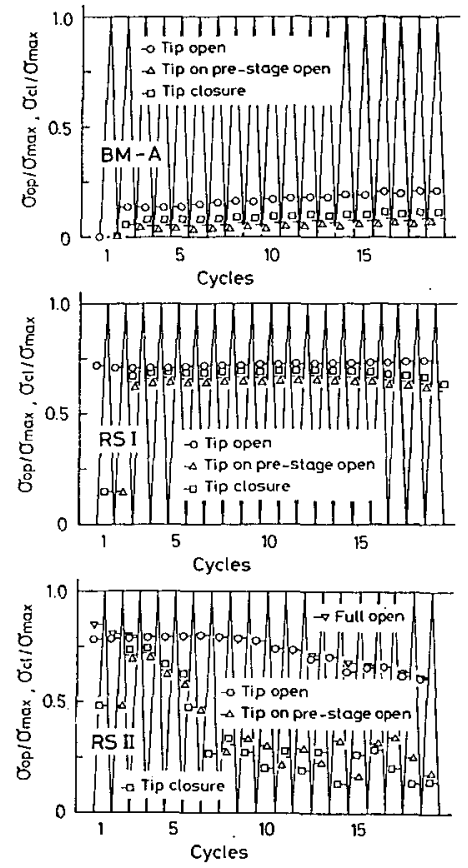

Fig. 11 Variation in crack tip opening and closing stress level according to load cycles (Upper; BM-A, Middle; RS I, Lower; RS II)

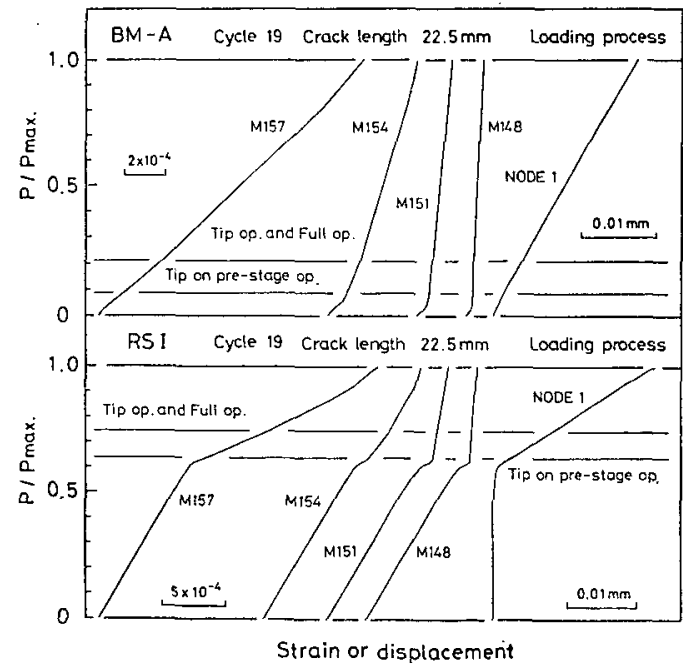

Fig. 12 Hysteresis curves of load-strain of elements and load-displacement of node on loading process (Upper; BM-A Cycle 19, Lower; RS I Cycle 19)

Fig. 3 にO印で示した要素のうち，き裂先端後方に位 置する要素および原点位圆の節点 (NODE 1) の負荷過 程での荷重軸 $(Y)$ 方向䄳, 変位の変化を Fig. 12, 13 に示す.ここで M 157 の $X$ 方向への要素重心は 22.0 $\mathrm{mm}$ であり, 要素番号が若くなるにつれ $0.8 \mathrm{~mm}$ づつ重 心位置か短くなる。 BM-A の M 157 Kは Tip on pre- 


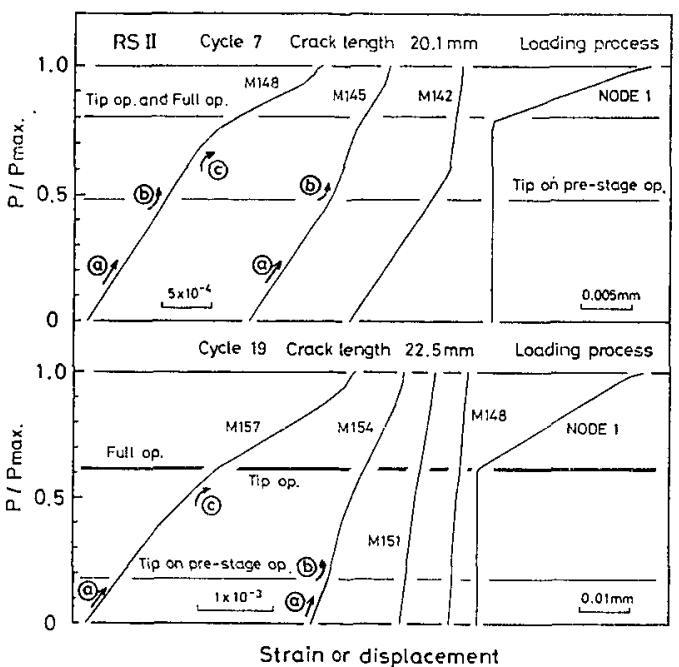

Fig. 13 Hysteresis curves of load-strain of elements and load-displacement of node on loading process of RS II (Upper; Cycle 7, Lower; Cycle 19)

stage op. と Tip op. の間にかすかなおれまがりが珰め られる。

また RS I の M 157 には Tip on pre-stage op. で 明らかな屆曲点があり（この屈曲点までは主としてき裂 面上の王縮雪が解放される過程であり，それ以上では外 力による歪集中のための変化である)，Tip op. ではそれ ほよ゙明碓ではない，奏際の疲学き裂の伝播速度は栖めて 小さく, 本解析での Tip on pre-stage op. とはほぼ一致 しているむのと考えられるため，実験的にはとの屈曲点 を開口点之考元て良いと思われる. ICRSF から ITRSF にき裂が進展する時 (Fig. 13) には, Tip op. 上 Tip on pre-stage op. の差が大きく, 各位置で $2 つ 0$ 屈曲点を生 じる. 残存開口部を持たない場合 (Gycle 7) には初期に 直線的（@）な変化を示し，その後わずかに下に山

(b) の曲線となる（この間で局部的な開口が生じ圧維 残留正が解放される。) そしてき裂後方が大きく開口す

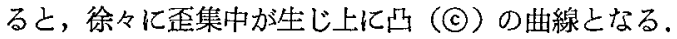

明らかな残留開口がある場合には（Cycle 19）初期の(a) 部が筷くなり，(の領域が広くなる，き裂がさらに伝播 すると Tip on pre-stage op. は零となるあのと考えら れるため，この Tip on pre-stage op. が実験的な開口点 に対応するものと思われる。

これらの䄳変化はいずれの場合もき裂先端後方 0.5 $1 \mathrm{~mm}$ の位置で最す大きく，き裂先端から離れるにつれ て屈曲点が荷重の小さい側で生じるようになる。これは 要素直下のき裂面が開口した時に屈曲が生じるためであ り, 昰ゲージの貼付位置とき裂先端の相対位監には充分 な注意が必要である。なお上述した歪変化の傾问は既 報4)の実験結果亡良く刘応しており，き裂面近傍での柾 ゲージによる開閉口挙動の検討結果が努当なあのである ことがわかる

一方, NODE 1 の曲線を見ると, BM-A では Tip op. 付近に詳細に見ればわずかなおれまがりがあり，そ の他の場合には蹎著な風曲か認められる。また，いずれ の場合む Tip op. 付近以下ではほぼ直線的な変化を示
す。すなわはき裂中央部での開口変位曲線には複雑な閶 閉口挙動の情報が表われにくいことがわかる。

\section{5 き裂面上の残留応力分布と $\sigma_{i_{2}} \mathrm{~s}$}

一般に閉口していたき裂が開口しようとする瞬間まで はき裂周辺に何らの望性変形す生じないと考えられるた め，弾性問題として取り扱うことを試みる。

き裂先端部の開口および応力状繁の模式図を Fig. 14 亿示す. (a)は最小荷重の状熊を示す，(b 1) と（b 2)を (a)に重ね合わせればき裂開口時の状態(c)となる、なお， （b 1)，（b 2）は塑性域を考慮した Dugdale-Barenblatt

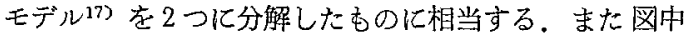
の $K_{a}, K_{b 1}, K_{b 2}, K_{c}$ は各状態での応力拡大係数であ る、ことで(a)，(c)ではき裂先端での特異場が存在しない ため， $K_{b 1}+K_{b 2}=0$ でなければならない，すなわち， $K_{b 1}$ と $K_{b 2}$ の絶対值は等しくなる。般に実験で求ま る $K_{0 p}$ は $K_{b 2}$ であり，従って $K_{b 1}$ を求めれば $K_{o p}$ を 知ることができる。

無限板中に長さ 2 a のき裂があり，そのき裂面に上下 刘称な分布内压 $\sigma_{r}(x)$ が作用する場合，K值は次式で 与えられる ${ }^{18)}$.

$$
K=\frac{1}{\sqrt{\pi a}} \int_{-a}^{a} \sigma_{r}(x) \sqrt{\frac{a \pm x}{a \mp x}} d x
$$

解析結果より除荷特のき裂面の応力分布を Fig. 5 の上 うに仮定し，き裂左右で対称とすれば式(4)は次式のよう な区分積分に圈き加えられる。

$$
K=\frac{2 \sqrt{\pi a}}{\pi} \sum_{k=1}^{i} \sigma_{k}\left(\operatorname{Sin}^{-1} \frac{a_{k+1}}{a_{k}}-\operatorname{Sin}^{-1} \frac{a_{k}}{a}\right)
$$

式(5)より求めた $K$ 值を $K_{\text {res }}$ とする.なお Tip op. 時 にき裂面がまだ接触している場合には，接蚛部の応力伃 布を式(5)に代入し，得られた值の分だけ差し引いて $K_{r e s}$ 亡した.とのようにして求めた $K_{r e s}$ は無限板を仮定し ているため解析から得られる $K_{o p}$ とは端部効果の分だ げ一致しないことが考えられる。そこで開日応力に注目 することとした． $K_{\text {res }}$ を $\sqrt{\pi a}$ で除した值を $\sigma_{r e s}^{\mathrm{eq}}$ しし

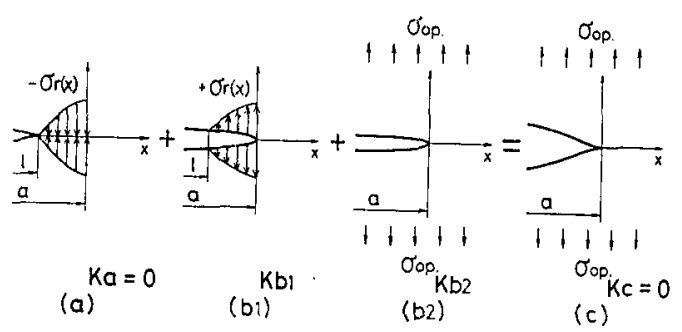

Fig. 14 Elastic superposition model for crack opening

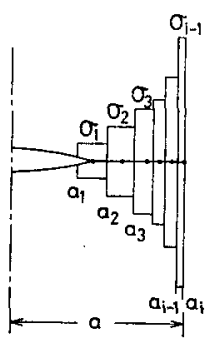

Fig. 15 Compressive residual stress distribution on crack plane 


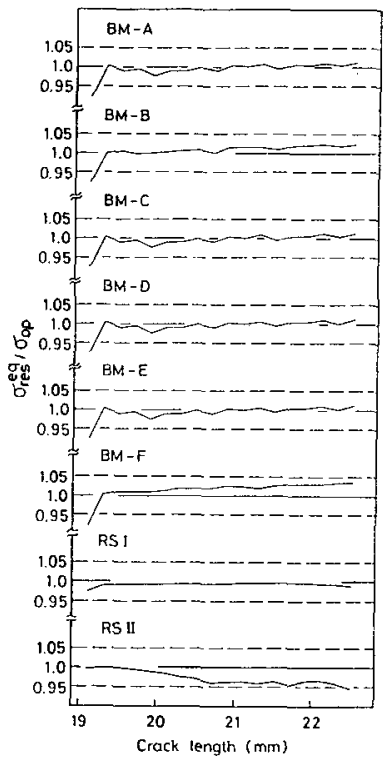

Fig. 16 Variation in $\sigma_{\text {res }}^{\text {eq }} / \sigma_{\text {op }}$ according to crack propagation

その值と解析から得られた $\sigma_{n p}$ との比とき裂長さの関 係を Fig. 16 に示す. 解析案件を変えた坐材, 残留応力 場での結果いずれの場合も約士5％60範国内で而者がー 致していることがわかる。すなわち同一のき裂長さを有 する無限板に圧縮残留応力場を代表するパラメータであ る $K_{r e s}$ 之等しい $K$ 値を与える等価な応力がき裂開口忍 力となる。

\section{4. 結言}

本研究で得られた主な結果を要約すると次のとおりで ある。

（1）き裂が初期圧縮残留応力場にある間は残留応力の 再分布はほとんど生じない，しかし初期引張残留応力場 にまで伝播すると明らかな再分布が起とる。これはき裂 先端の塑性域が熱源周辺の塑性域と合体すること，およ び残存開口部を生じることによるためである。

（2）き裂が初期圧縮残留応力場化ある間の開閉口挙動 は乎材でのそれ之傾向的に一致する。しかしき裂が初期 引張残留応力場に伝播するとき裂先端部に残存開口部を 生じ，き裂先端が開口した後にき裂全体が開口し，き裂 中央部が閉口した後に先端部が闒口するようになる。

（3）母村を含めてき裂面上の玨縮残留応力分布加万 き裂先端開口時の応力を求めることが可能である．特に
き裂が初期压縮残留応力場にある場合は，(1)の前半の結 論加ら初期残留応力分布を用いて良いあのと考えられ る.

（4）压縮残留応力場を伝播する疲学き裂の開閉口挙動 を実测する場合には，き裂面に近く，き裂先端後方 0.5 〜1 mm の位珇に歪ゲージを貼付しその外力-歪曲線を 注意深く理解することによって測定できる.

最後に本研究を遂行するにあたり多大な御協力を頂い 九当時大阪大学大学院生仲野修朗氏（現在侏神戸製鋼 所）に深く感謝します。また本研究の一部は昭和59年度 科学研究费補助金（奖励研究A）によったものであるこ とを記して謝意を表します。

\section{参 考 文 献}

1) W. Elder ; The significance of fatigue, crack closure, ASTM STP 486 (1971) p. 230-242

2) J. C. Newman, Jr. ; Fatigue-crack propagation and closure under variable-amplitude loading, Proc. of USJapan Cooperative Seminar (1981) p.169-178

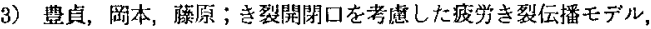
日本造船学会諭文集，第 152 号 (1983) p.381-389

4）向井，西村，金; 波労き裂の開閉口挙勒に及ぼす溶接残留応力の 影警江関する研究，溶接学会論文集，第 5 巻，第 1 号(1987) p.113119

5）太田，小菅，画島；压缩負荷を受りる溶接継手の波れき裂伝ぱ举

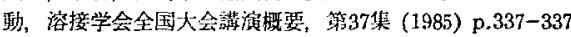

6）水本，原；エンジニアリングトイエンスのための有限要索法理馀 編，森北出版 (1983)

7）水本，原；エンジニアリングサイエンスのたぬの有限要点法プロ グラム編，森北出版 (1983)

8）上田，山川; 有限要絭法に上る熱弾塑性挙動の解析，溶接学会誌， 第 42 巻，第 6 号 (1973) p.567-577

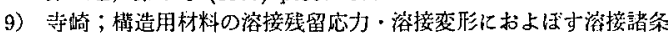

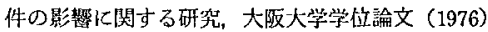

10）问井，四村；き裂少端近傍の变形举動に関する解析的検討，溶接 学会誌，第51巻，第10号 (1982) p.67-72

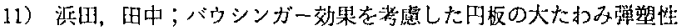

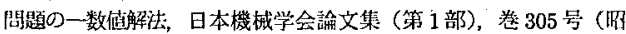
$47-1)$ p. $37-47$

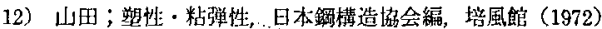

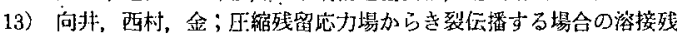

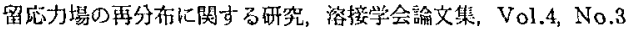
(1986) p.150-155

14) F. C. Lea and O. H. Crowther; The change of the modulus of elasticity and other properties of metals with temperature, Engineering, Vol.98 (1914) p.487-489

15) N. J. I Adams; Crack growth in the vicinity of welds, Weld. Res. Sup., Vol.52, No.11 (1973) p.508 s-513 s

16）向井，西村，金; 溶接残留纫力埸の再分在之疲労き裂の伝播举動， 溶接学会疲労強度委員会痈料, FS-658-84 (1984)

17）石田；き裂の弾性解析之纫力拡大绿数，培風館（1976）

18）戌村；線珍破壊力学入門，培風䬲（1976） 